\title{
The Influence of Recruitment and Position Competence on the Performance of State Civil Apparatus at the Regional Secretariat of Central Sulawesi Province
}

\author{
Sulaeha $^{1 *}$, Alam Anshary ${ }^{2}$, Nawawi Natsir ${ }^{3}$ \\ ${ }^{1}$ Social Science Study Program Postgraduate Doctoral Program, Tadulako University, Palu-Central Sulawesi, Indonesia \\ ${ }^{2}$ Faculty of Agriculture, Tadulako University, Palu-Central Sulawesi, Indonesia \\ ${ }^{3}$ Faculty of Social and Political Sciences, Tadulako University, Palu-Central Sulawesi, Indonesia
}

\begin{abstract}
This study aims to obtain information about the effect of (1) recruitment of positions on the performance of state civil servants in the Regional Secretariat Central Sulawesi Province, (2) position competence on the performance of the state civil apparatus in the Regional Secretariat Central Sulawesi Province, (3) recruitment of positions and job competencies simultaneously or partially on the performance of state civil servants at the Regional Secretariat of Central Sulawesi Province. The method used is the survey method with quantitative descriptive data analysis techniques. The target population is all civil servants of the Regional Secretariat of Central Sulawesi Province, as many as 498 people. The number of research samples was 222 people using the Proportional Random Sampling technique. The study results show that: First, there is a positive and significant influence between the performances of the state civil apparatus in the Secretariat of Central Sulawesi Province with a value of 14.2\%. Second, there is a positive and significant influence between the performance of state civil servants in the Regional Secretariat of Central Sulawesi Province with a value of $34 \%$. Third, there is a positive and significant influence jointly between job recruitment and job competence with a positive effect with a value of $48.3 \%$.
\end{abstract}

Keywords: Job Recruitment, Position Competence, ASN Performance

\section{INTRODUCTION}

$\mathrm{H}$ uman Resources (HR) is an important factor in an organization or government in providing services to the public (Mutiana et al., 2017; Lazarova et al., 2021). The development and professional development of HR is one of the exemplary efforts to face and respond to all challenges related to changes in the strategic environment. The realization of skilled human resources of the apparatus through the management of individual performance is one of the government's efforts in encouraging the organization's success in achieving the goals and objectives that have been set. One of the integrated HR management can be done through a measurable employee performance appraisal system in supporting organizational achievements(Alserhan \& Shbail, 2020; Rizun et al., 2021). Employees, in this case, are defined as assets for the organization, so they need to be managed and nurtured appropriately to produce a performance that can support the achievement of organizational goals.

Recruitment of positions (administration) at the regional secretariat of Central Sulawesi province by not using the merit system as a basis for assessment results in the low professionalism of government officials in carrying out their duties and functions. At the same time, the merit system is a mechanism that is considered the most appropriate in the development of bureaucratic human resources because it provides an illustration of proportional and professional bureaucratic management. This is supported by opinion(Ali \& Sagsan, 2020; Delbari et al., 2021)who said that HR who contributed and had a higher capacity had a greater chance of obtaining career development and achievement than HR who contributed and had a lower ability. Suppose the recruitment or filling of administrative positions is carried out openly. In that case, it will give every ASN the same opportunities to sit in a certain position as long as they have the required competencies. ASN who cannot develop their competence will be directly eliminated by another ASN who has more competence. Thus, it will be easier to find reliable and professional ASN due to increasing competition to demonstrate their quality.

Recruitment process for positions in the bureaucracy still uses the old paradigm in filling positions and tends to be oriented towards career development of ASN in stages in the agency and less emphasis on aspects of work performance and competence. This has negative implications in weak competition, lack of motivation, and inefficient bureaucracy(Ali \& Sagsan, 2020). The low, competitive spirit then impacts the lack of initiative from ASN to develop themselves to improve the quality of their performance. At the same time, ASN is the main driving force in the bureaucracy and determines the good or bad performance of the government bureaucracy. If the quality of work tends to 
stagnate, it will be challenging to create a reliable and professional ASN.

Another problem currently in the main focus is the recruitment process for government employees/officials, which is not transparent and tends to use a closed career system, which prioritizes the role of superior officials in appointing officials with positions below them. (Mokodongan et al., 2019; Faiz et al., 2020). This kind of process is primarily determined based on political, familial, and economic relations, which are very thick with the content of corrupt practices, collusion, nepotism, and so on, which do not reflect the noble values of the appointment of officials themselves. In addition to the recruitment process or filling positions that are not appropriate, the performance of the state civil apparatus can be affected by the competence of the work. Competence is an essential characteristic possessed by a person that allows superior performance in a particular job, role or situation, including motives, personal character, selfconcept, knowledge, and skills. According to(As'ad \& Kamidin, 2020), competence is essential and plays a role in improving employee performance or performance.

In evaluating employee performance, it is necessary to have an instrument representing the performance itself (Lohman, 2021). According to other opinions, performance can be seen based on the quality of work, quantity of work, samples of a task that are part of the job, the time it takes to learn a lesson, and the number of promotions exceeded. (Setiawan, 2018). ASN Performance in the regional secretariat of the province of Central Sulawesi as a staff element that carries out the task of assisting the governor in policy formulation and administrative coordination on the implementation of regional apparatus tasks and administrative services marked with some regional deviceProvinces and regencies/cities are dissatisfied with the services provided. Some ASNs still like to come in late and go home early so that services don't run smoothly. Such a situation makes regional device other people, and the community as users of public services are not satisfied. Therefore, it is necessary to cause severe and comprehensive improvements in improving performance at the regional secretariat office of Central Sulawesi province.

\section{LITERATURE REVIEW}

\section{There are Several Studies}

There are several studies that have been carried out by other researchers that are relevant to the title and problems studied in this study. Therefore, previous studies need to be described in order to formulate the dimensions of similarities and differences with this study as follows:
1. Yohamir Syamsu's (2015) dissertation entitled "The Influence of Recruitment, Competence, Motivation and Job Satisfaction on the Performance of Middle School Supervisors in East Priangan" The results also show that simultaneously recruitment, competence, motivation, and job satisfaction have a significant effect on supervisor performance. Based on the results of the study, it is recommended that the existence of supervisors is not only used as a complement in an education management system for local governments.

2. Yana Sjofjan's dissertation (2020) entitled "The Influence of Social Intelligence, Spiritual Intelligence, Emotional Intelligence, Recruitment Effectiveness and Selection on Principals at YPI Al-Azhar Environment in Jakarta" The research was conducted using quantitative methods and data analysis and processed using Partial Least Squares (PLS) analysis. The results of this study are 1) Social intelligence has a significant effect on the effectiveness of leadership performance; 2) Social intelligence does not directly affect the effectiveness of recruitment and selection; 3) Spiritual intelligence affects the performance of the leadership can be proven true; 4) Spiritual intelligence has an indirect effect on recruitment; 5) Emotional intelligence has a direct effect on the performance of the leader; 6) Emotional intelligence has an indirect effect on recruitment; 7) Recruitment has no significant effect on the leader's performance.

3. Jazilul Fawaid's Dissertation (2020) entitled "The Influence of Recruitment, Competence and Organizational Commitment on the Performance of DPR RI Members for the 2014-2019 Period. Doctoral thesis, Jakarta State University" This study concludes as follows: (1) There is a positive direct effect of the recruitment of members of the DPR RI on performance, (2) There is a direct positive effect of the competence of members of the DPR RI on performance, (3) There is a direct positive effect of organizational commitment of the DPR RI on performance, (4) There is a positive direct effect of DPR RI recruitment on commitment, (5) There is a positive direct influence of DPR RI competence on organizational commitment, (6) There is a positive indirect effect of DPR RI recruitment on performance through organizational commitment, and (7) There is a positive indirect effect of competence on performance through organizational commitment. 
Table 1. Equation and Difference Matrix Previous Research with this Research

\begin{tabular}{|c|c|c|c|c|}
\hline No & Writer & Title & Equality & Difference \\
\hline 1 & $\begin{array}{l}\text { Yohamir } \\
\text { Syamsu }\end{array}$ & $\begin{array}{l}\text { The Effect of Recruitment, } \\
\text { Competence, Motivation } \\
\text { and Job Satisfaction on the } \\
\text { Performance of Middle } \\
\text { School Supervisors in } \\
\text { Priangan Timur }\end{array}$ & $\begin{array}{l}\text { 1. Using the same approach, namely } \\
\text { quantitative. } \\
\text { 2. The variables studied are } \\
\text { relatively the same, namely } \\
\text { recruitment, competence, and } \\
\text { performance } \\
\text { 3. Both use research methodologies, } \\
\text { namely quantitative and data } \\
\text { analysis, namely Path Analysis }\end{array}$ & $\begin{array}{l}\text { 1. Study Yohamir Syamsu used } 3 \text { predictors } \\
\text { while this study used } 2 \text { predictors. } \\
\text { 2. Overall researchYohamir Syamsu examines } \\
4 \text { variables, namely } 3 \text { independent } \\
\text { variables and } 1 \text { dependent variable, while } \\
\text { this study examines } 3 \text { variables, namely } 2 \\
\text { independent variables and } 1 \text { dependent } \\
\text { variable }\end{array}$ \\
\hline 2 & $\begin{array}{l}\text { Yana } \\
\text { Sjofjan }\end{array}$ & $\begin{array}{l}\text { The Influence of Social } \\
\text { Intelligence, Spiritual } \\
\text { Intelligence, Emotional } \\
\text { Intelligence, Effectiveness } \\
\text { of Recruitment and } \\
\text { Selection on Principals at } \\
\text { YPI Al-Azhar } \\
\text { Environment in Jakarta" }\end{array}$ & $\begin{array}{l}\text { 1. Using the same approach, namely } \\
\text { quantitative. } \\
\text { 2. The variables studied were the } \\
\text { same, namely recruitment and } \\
\text { performance }\end{array}$ & $\begin{array}{l}\text { 1. Study Yana Sjofjan uses data analysis } \\
\text { techniques, namely Partial Least Squares } \\
\text { (PLS) analysis, while this study uses path } \\
\text { analysis. } \\
\text { 2. study Yana Sjofjan examine } 6 \text { variables, } \\
\text { namely } 5 \text { independent variables and } 1 \\
\text { dependent variable } \\
\text { while the research only uses } 3 \text { variables, } \\
\text { namely } 2 \text { independent variables and } 1 \\
\text { dependent variable }\end{array}$ \\
\hline 3 & $\begin{array}{c}\text { Jazilul } \\
\text { Fawaid }\end{array}$ & $\begin{array}{l}\text { The Influence of } \\
\text { Recruitment, Competence } \\
\text { and Organizational } \\
\text { Commitment on the } \\
\text { Performance of DPR RI } \\
\text { Members for the 2014- } \\
2019 \text { Period. Doctoral } \\
\text { thesis, Jakarta State } \\
\text { University }\end{array}$ & $\begin{array}{l}\text { 1. Equally Use the quantitative } \\
\text { approach method } \\
\text { 2. The variables studied are } \\
\text { relatively the same, namely } \\
\text { recruitment, competence and } \\
\text { performance } \\
\text { 3. Both use data analysis, namely } \\
\text { Path Analyst }\end{array}$ & $\begin{array}{l}\text { 1. Research variableJazilul Fawaid examines } 4 \\
\text { variables, namely } 3 \text { independent variables } \\
\text { and } 1 \text { dependent variable, while this study } \\
\text { examines } 3 \text { variables, namely } 2 \\
\text { independent variables and } 1 \text { dependent } \\
\text { variable }\end{array}$ \\
\hline
\end{tabular}

\section{RESEARCH METHODS}

\section{Types of research}

The type of quantitative research used in this research is explanatory. According to (Hymel, 2002)"Explanatory research is descriptive research that highlights the causal relationship between research variables and tests the hypotheses that have been formulated previously. The type or design of this research was chosen because it was considered capable of describing and explaining empirical facts in the field and analyzing the influence of independent variables either partially or simultaneously on the dependent variable.

\section{Research Location and Time}

A research location is where researchers carry out research activities to obtain the data needed to answer the problems set. According to (Das 2021), the best way to determine the research location is by defending a substantive theory go and explore the field to see if there is a match and reality in the area. Geographical and practical limitations such as time, cost and workforce need to be considered in the research location. Based on this view, the researchers chose the research location, namely the regional secretariat office of the province of Central Sulawesi.

\section{Population, Sample and Sampling Technique}

The population is the entire subject that is the focus of research. The issues in this study were all state civil servants in the regional secretariat of Central Sulawesi province, totalling 498 people consisting of 9 organizational units (bureaus), as shown in the following table.

Table 1. Number of ASN by Gender and Type of Position Regional Secretariat of Central Sulawesi Province.

\begin{tabular}{|c|c|c|c|c|c|c|c|c|c|}
\hline \multirow{2}{*}{$\begin{array}{l}\mathrm{N} \\
\mathrm{o}\end{array}$} & \multirow{2}{*}{$\begin{array}{c}\text { Organizatio } \\
\text { nal Unit }\end{array}$} & \multirow{2}{*}{$\begin{array}{l}\text { Qua } \\
\text { ntity }\end{array}$} & \multicolumn{2}{|c|}{ Gender } & \multicolumn{4}{|c|}{ Type of Position } & \multirow{2}{*}{$\begin{array}{l}\mathrm{N} \\
\text { ot } \\
\mathrm{e}:\end{array}$} \\
\hline & & & $\mathrm{L}$ & $\mathrm{P}$ & $\begin{array}{c}\text { ice. } \\
2\end{array}$ & $\begin{array}{c}\text { ice. } \\
3\end{array}$ & $\begin{array}{c}\text { ice. } \\
4\end{array}$ & $\begin{array}{c}\text { Execut } \\
\text { or }\end{array}$ & \\
\hline 1. & $\begin{array}{l}\text { Administrat } \\
\text { ion Bureau. } \\
\text { Social } \\
\text { Welfare and } \\
\text { Community }\end{array}$ & 48 & 17 & 31 & 1 & 3 & 9 & 35 & \\
\hline 2. & $\begin{array}{c}\text { Bureau of } \\
\text { Procuremen } \\
t \text { of Goods } \\
\text { and } \\
\text { Services }\end{array}$ & 45 & 25 & 20 & 1 & 3 & 9 & 32 & \\
\hline 3. & $\begin{array}{c}\text { Administrat } \\
\text { ion Bureau. } \\
\text { Economy } \\
\text { and } \\
\text { Developme } \\
\text { nt }\end{array}$ & 53 & 29 & 24 & 1 & 3 & 8 & 41 & \\
\hline 4. & $\begin{array}{l}\text { Administrat } \\
\text { ion Bureau. } \\
\text { Regions and } \\
\text { Government }\end{array}$ & 22 & 13 & 9 & 1 & 3 & 9 & 9 & \\
\hline 5. & $\begin{array}{l}\text { Bureau of } \\
\text { Public } \\
\text { Relations } \\
\text { and } \\
\text { Protocol }\end{array}$ & 31 & 16 & 15 & 1 & 3 & 8 & 19 & \\
\hline
\end{tabular}




\begin{tabular}{|c|c|c|c|c|c|c|c|c|}
\hline 6. & $\begin{array}{c}\text { Legal } \\
\text { Bureau }\end{array}$ & 35 & 16 & 19 & 1 & 3 & 9 & 22 \\
\hline 7. & $\begin{array}{c}\text { Organizatio } \\
\text { n Bureau }\end{array}$ & 35 & 19 & 16 & 1 & 3 & 9 & 22 \\
\hline 8. & $\begin{array}{c}\text { Regional } \\
\text { Autonomy } \\
\text { Bureau }\end{array}$ & 42 & 18 & 24 & 1 & 3 & 9 & 29 \\
\hline 9. & $\begin{array}{c}\text { General } \\
\text { Bureau }\end{array}$ & 187 & $\begin{array}{c}10 \\
9\end{array}$ & 78 & 1 & 3 & 9 & 174 \\
\hline \multicolumn{2}{|r|}{ Amount } & 498 & $\begin{array}{c}26 \\
2 \\
\end{array}$ & $\begin{array}{c}23 \\
6 \\
\end{array}$ & 9 & 27 & 79 & 383 \\
\hline
\end{tabular}

Data Source: Statistics Book of the Provincial Civil Service Agency. Central Sulawesi

The number of samples determined in this study, using the formula for determining the number of samples proposed by Slovin (Adam, 2020), namely:

$\mathrm{n}=\mathrm{N} /(1+\mathrm{N} .(\mathrm{e}) 2)$

The formula can be given the following information:

$\mathrm{n}=$ number of samples (number of samples)

$\mathrm{N}=$ Total population (sum of all members of the population)

$\mathrm{e}=$ Error tolerance $(0.05$ tolerance $)$

Based on Slovin, there are several things that need to be explained further that in order to determine the number of samples, it is necessary to first know the size of the population. By knowing the population size as mentioned above, the Slovin formula in this study can be described as follows:

$\mathrm{n}=\mathrm{N} /(1+\mathrm{N} .(\mathrm{e}) 2)$

$\mathrm{n}=498 /(1+498 .(5 \%) 2) \mathrm{n}=498 /(1+498 .(0.05) 2) \mathrm{n}=498$

$/(1+498 .(0.0025)) \mathrm{n}=498 /(1+1,245) \mathrm{n}=498 / 2,245 \mathrm{n}=$

221,826 (rounded up to 222).

Thus, the number of samples in this study was set at 222 people. The next thing that needs to be decided is who is included in the 222 people as representatives of the population. The regional secretariat of Central Sulawesi province consists of 9 organizational units (bureaus). Each bureau has members (ASN) whose number is different, so it is necessary to determine the sample unit. Related to that, this research uses a proportional random sampling technique. This technique is used because the population has members that are not homogeneous; in this case, the number of members from each unit/bureau is different. In determining the number of samples for each unit (bureau), it is calculated proportionally using the formula:

Information: $\mathrm{s}=$ number of samples per unit proportionally,

$\mathrm{S}=$ the total number of samples obtained,

$\mathrm{N}=$ Total Population,

$\mathrm{n}=$ the number of each population unit

Based on the above formula, the number of samples for each unit/bureau is obtained as shown in the following table.

Table 2. Number of Samples of Each Organizational Unit Proportionately

\begin{tabular}{|c|c|c|c|c|}
\hline $\begin{array}{c}\mathrm{N} \\
\mathrm{o}\end{array}$ & Organizational Unit & $\begin{array}{c}\text { Number } \\
\text { of } \\
\text { populatio } \\
\mathrm{n}\end{array}$ & $\mathrm{s}=\mathrm{n} / \mathrm{N} \times \mathrm{S}$ & $\begin{array}{c}\text { Sampl } \\
\text { e unit }\end{array}$ \\
\hline 1 & $\begin{array}{c}\text { Administration Bureau. } \\
\text { Social Welfare and } \\
\text { Community }\end{array}$ & 48 & $48 / 498 \times 222$ & 21 \\
\hline $\begin{array}{c}2 \\
.\end{array}$ & $\begin{array}{c}\text { Bureau of Procurement } \\
\text { of Goods and Services }\end{array}$ & 45 & $45 / 498 \times 222$ & 20 \\
\hline 3 & $\begin{array}{c}\text { Administration Bureau. } \\
\text { Economy and } \\
\cdot\end{array}$ & 53 & $53 / 498 \times 222$ & 23 \\
\hline 4 & $\begin{array}{c}\text { Administration Bureau. } \\
\text { Regions and } \\
\text { Government }\end{array}$ & 22 & $22 / 498 \times 222$ & 10 \\
\hline 5 & $\begin{array}{c}\text { Bureau of Public } \\
.\end{array}$ & 31 & $31 / 498 \times 222$ & 14 \\
\hline 6 & Relations and Protocol \\
. & Legal Bureau & 35 & $35 / 498 \times 222$ & 16 \\
\hline 7 & Organization Bureau & 35 & $35 / 498 \times 222$ & 16 \\
\hline 8 & Regional Autonomy \\
Bureau8787Y & 42 & $42 / 498 \times 222$ & 19 \\
\hline 9 & General Bureau & 187 & $187 / 498 \times 222$ & 83 \\
\hline. & Amount & 498 & & 222 \\
\hline
\end{tabular}

\section{Variable Operations}

Based on theoretical studies, it can be operationally confirmed that the variables studied in this study are:

\section{Job recruitment}

Recruitment is the process of generating a pool of qualified applicants for a job.

\section{Position Competence}

Competence is the essential characteristics (underlying characteristics) of individuals related to the criteria for effective and superior performance in work; these important characteristics will affect individual behaviour and ultimately are reflected in the version produced by the individual.

\section{Performance}

Performance is the result achieved by a person according to the size applicable to the job in question. 
Table 2. Research Variables and Indicators

\begin{tabular}{|c|c|c|}
\hline Variable & Dimension & Indicator \\
\hline \multirow{3}{*}{$\begin{array}{l}\text { RECRUITMENT OF } \\
\text { POSITION (X1) } \\
\text { "Recruitment is the process of } \\
\text { producing a group of applicants } \\
\text { who are qualified for a job. } \\
\text { (Robert L. Mathis 2011) }\end{array}$} & $\begin{array}{l}\text { Recruitment Basis } \\
\text { "Facts that must support job recruitment" }\end{array}$ & $\begin{array}{l}\text { a. There are clear rules } \\
\text { b. vacancies/vacant positions } \\
\text { c. Financing }\end{array}$ \\
\hline & $\begin{array}{c}\text { Recruitment source } \\
\text { "Vacancy given to fill position" }\end{array}$ & $\begin{array}{l}\text { a. Withdrawal Sources from within the organizational unit } \\
\text { b. Sources of withdrawal from outside the organizational unit }\end{array}$ \\
\hline & $\begin{array}{l}\text { Recruitment method } \\
\text { "Activities on how to attract prospective } \\
\text { employees to apply or fill positions }\end{array}$ & $\begin{array}{l}\text { a. Job rotation } \\
\text { b. Job promotion } \\
\text { c. Position assessment/auction }\end{array}$ \\
\hline \multirow{5}{*}{$\begin{array}{l}\text { POSITION COMPETENCY } \\
\text { (X2) } \\
\text { "Competence is the basic } \\
\text { characteristics (underlying } \\
\text { characteristics) of individuals } \\
\text { related to the criteria for } \\
\text { effective and superior } \\
\text { performance in work, these } \\
\text { basic characteristics will affect } \\
\text { individual behavior and are } \\
\text { ultimately reflected in the } \\
\text { performance produced by the } \\
\text { individual. } \\
\text { (Spencer and Spencer, 2011) }\end{array}$} & $\begin{array}{l}\text { Motive: } \\
\text { The driving force that will realize a } \\
\text { behavior in order to achieve the goal of self- } \\
\text { satisfaction. }\end{array}$ & $\begin{array}{l}\text { a. Ability to understand the authority and responsibility of } \\
\text { structures within the organization } \\
\text { b. Ability to build close relationships with the social } \\
\text { environment } \\
\text { c. Responsibility for work } \\
\text { d. Achievement oriented }\end{array}$ \\
\hline & $\begin{array}{c}\text { Nature } \\
\text { "The character that makes people behave or } \\
\text { how someone responds to something in a } \\
\text { certain way" }\end{array}$ & $\begin{array}{l}\text { a. Ability to develop others } \\
\text { b. Ability to guide other employees in achieving their goals } \\
\text { c. Ability to work together in a team } \\
\text { d. Ability to act as a leader } \\
\text { e. Ability to understand the needs of other employees } \\
\text { f. Desire to serve customers }\end{array}$ \\
\hline & $\begin{array}{c}\text { Self concept } \\
\text { "Attitudes and values of an employee" }\end{array}$ & $\begin{array}{l}\text { a. Ability to control emotions } \\
\text { b. Ability to avoid negative/harmful actions at work } \\
\text { c. Confidence in one's own ability to complete tasks } \\
\text { d. Ability to adapt to various situations } \\
\text { e. Ability to work effectively in various situations } \\
\text { f. Ability to respect differences of opinion/opinion } \\
\text { g. Ability to put organizational goals as a priority }\end{array}$ \\
\hline & $\begin{array}{l}\text { Knowledge } \\
\text { "Information that a person has in a } \\
\text { particular field" }\end{array}$ & $\begin{array}{l}\text { a. Ability to understand situations in detail } \\
\text { b. Systematic thinking ability } \\
\text { c. The ability to see things as a whole } \\
\text { d. Creative thinking skills } \\
\text { e. Knowledge of assigned work }\end{array}$ \\
\hline & $\begin{array}{c}\text { Skills } \\
\begin{array}{c}\text { "The ability to carry out certain physical or } \\
\text { mental tasks" }\end{array}\end{array}$ & $\begin{array}{l}\text { a. Ability to reduce job uncertainty } \\
\text { b. Ability to act beyond what is needed to improve work } \\
\text { outcomes } \\
\text { c. Ability to influence others to support ideas } \\
\text { d. Ability to collect more information in completing work }\end{array}$ \\
\hline \multirow{8}{*}{$\begin{array}{l}\text { PERFORMANCE (Y) } \\
\text { "Performance is the result } \\
\text { achieved by a person according } \\
\text { to the applicable standards for } \\
\text { the job in question" } \\
\text { (Gomez, 1998) }\end{array}$} & $\begin{array}{c}\text { Quality of Work } \\
\text { "The quality of work achieved is based on } \\
\text { the requirements of suitability and } \\
\text { readiness" }\end{array}$ & $\begin{array}{ll}\text { a. } & \text { Accuracy in work } \\
\text { b. } & \text { Accuracy and completeness }\end{array}$ \\
\hline & $\begin{array}{c}\text { Job Quantity } \\
\text { "Amount of work done in a given period of } \\
\text { time" }\end{array}$ & $\begin{array}{ll}\text { a. } & \text { Busy work level } \\
\text { b. } & \text { Job volume }\end{array}$ \\
\hline & $\begin{array}{l}\text { Position Knowledge } \\
\text { "Extensive knowledge of the job and its } \\
\text { Skills" }\end{array}$ & $\begin{array}{l}\text { a. } \quad \text { Mastery of the field of work } \\
\text { b. } \\
\text { Experience in the field of work }\end{array}$ \\
\hline & $\begin{array}{l}\text { Cooperation } \\
\text { "Willingness to cooperate with others" }\end{array}$ & $\begin{array}{ll}\text { a. } & \text { Respect other people's opinion } \\
\text { b. } & \text { Have wide association } \\
\text { c. } & \text { Develop cooperation }\end{array}$ \\
\hline & $\begin{array}{c}\text { Initiative } \\
\text { "The spirit to carry out new tasks in } \\
\text { enlarging their responsibilities" }\end{array}$ & $\begin{array}{l}\text { a. Give positive ideas } \\
\text { b. } \quad \text { Actively provide suggestions for improvement }\end{array}$ \\
\hline & $\begin{array}{c}\text { Creativity } \\
\text { "Ideas that arise and actions to solve } \\
\text { problems that arise" }\end{array}$ & Creating creativity to improve work results \\
\hline & $\begin{array}{l}\text { Interdependence } \\
\text { "Awareness and trustworthy in terms of } \\
\text { attendance and completion of work" }\end{array}$ & Mutual need with other work units \\
\hline & $\begin{array}{l}\text { Self quality } \\
\text { "Regarding personality, leadership, } \\
\text { hospitality and personal integrity" }\end{array}$ & $\begin{array}{l}\text { Don't abuse authority } \\
\text { Act objectively }\end{array}$ \\
\hline
\end{tabular}

Source: Processed by researchers from the study of job recruitment theory, job competence, and performance theory 
The exogenous variable (X1) Job Recruitment has 8 indicators, the exogenous variable (X2) Position Competence has 26 indicators, and the endogenous variable (X3) has 15 indicators. Thus, the overall indicators in this study are 49 indicators as a description of the good research variables. independent variable (exogenous) and dependent variable (endogenous). However, it should be explained that these indicators, which will be described in the research instrument, are very likely to decrease after the instrument is empirically validated.

\section{Data Validation and Analysis Techniques}

\section{Instrument Validity and Reliability \\ - Data Validity Test \\ - Data Reliability Test}

\section{Analysis technique}

The data analysis technique consists of classical assumption test or requirements test and hypothesis testing in this study using SPSS or Statistical Package for the Social Sciences version 21.0. Before testing the hypothesis, begins with testing requirements or classical assumption tests to ensure that the research data can be analyzed using parametric tests. The test requirements include:

1. The normality test is a test of requirements that aims to test whether a model of the independent variable and the dependent variable or both have data that is typically distributed.

2. The multicollinearity test is intended to determine whether the independent variables are not correlated with each other or, in other words, all the independent variables in the regression model have a linear relationship (not associated with each other).

3. The heteroscedasticity test is a test of requirements to determine whether there is a deviation from the model because the variance of the disturbance is different from one observation to another.

1) Linearity Test, which aims to determine whether two variables have a linear relationship or not significantly.

After testing the requirements and all the data meets the requirements to be continued in the parametric test. The hypothesis testing will be continued by using path analysis, commonly called path analysis, which is a technique that develops multiple linear regression.

\section{RESULTS AND DISCUSSION}

Result

Test Requirements Analysis
Table 3. Requirements Analysis Test Results

\begin{tabular}{|c|c|c|c|}
\hline No & $\begin{array}{c}\text { Test } \\
\text { Requirements }\end{array}$ & $\begin{array}{c}\text { Significant } \\
\text { Criteria }\end{array}$ & Information \\
\hline 1 & $\begin{array}{c}\text { Data Normality } \\
\text { Test }\end{array}$ & p-value $>0.05$ & Normal Distributed Data \\
\hline 2 & $\begin{array}{c}\text { Multicollinearity } \\
\text { Test }\end{array}$ & VIF value $<5$ & $\begin{array}{c}\text { There is no problem with } \\
\text { Multicollinearity }\end{array}$ \\
\hline 3 & $\begin{array}{c}\text { Heteroscedasticity } \\
\text { Test }\end{array}$ & $\begin{array}{c}\text { sig value }> \\
0.05\end{array}$ & $\begin{array}{c}\text { There is no } \\
\text { heteroscedasticity }\end{array}$ \\
\hline 4 & Linearity Test & $\begin{array}{c}\text { sig value }< \\
0.05\end{array}$ & Have a linear relationship \\
\hline
\end{tabular}

After testing the requirements of the hypothesis or testing the classical assumptions consisting of; normality test, multicollinearity test, heteroscedasticity test, and linearity test whose results are all types of tests required in path analysis pass the test or meet the requirements of the classical assumption test, then the hypothesis test can be continued.

\section{Hypothesis test}

In this study, what will be tested are 1) the effect of job recruitment and job competence on the performance of state civil servants in the secretariat of the province of Central Sulawesi; and 2) how much influence job recruitment and job competency have simultaneously on the performance of state civil servants in the secretariat of Central Sulawesi province.

1. Testing the Position Recruitment HypothesisPerformance of State Civil Apparatus

Thus, it is firmly stated that based on the results of the path analysis, it is concluded that the objective variable of job recruitment has a significant and contributory effect on the performance of the apparatus in the regional secretariat of Central Sulawesi province.

2. Position Competency Hypothesis Testing Performance of State Civil Apparatus

Based on p-value or sig $0.00<0.05$, namely the competence of the position gives meaning to affect the performance of the state civil apparatus in the regional secretariat of Central Sulawesi province

3. Hypothesis Testing Position Recruitment, Position Competence and Performance of State Civil Apparatus

Of course, between the two exogenous variables, namely job recruitment and job competence, they have different magnitudes of influence. To find out and analyze which variable has the greatest influence, it can be seen directly in Table 4.36 or the SPSS output Appendix 9. In column $t$ results $(t$ count) the difference in the magnitude of the influence of each exogenous variable can be seen. For the Recruitment variable count $=4,309$ and the Competence variable count $=11,968$, and. Thus, the biggest influence is the variable of position 
competence on the performance of the state civil apparatus

\section{DISCUSSION}

Position Recruitment has a Positive (Partial) Effect on the Performance of the State Civil Apparatus at the Regional Secretariat of Central Sulawesi Province.

The results of the research and analysis using SPSS objectively show that the variable $\mathrm{X} 1$ job recruitment contributes significantly or has a significant effect on the performance of the state civil apparatus in the regional secretariat of Central Sulawesi province. Statistically, it is proven by the acquisition of the value of the frequency distribution with the answer of the lowest indicator variable $\mathrm{X} 1$ having an average value score (mean) of 4.04, meaning that if the frequency distribution value is above the value of 0.05 , it means that the analysis of the frequency distribution proves that there is a significant effect between the variables. Job recruitment with performance. Furthermore, statistical evidence also shows the acquisition of the highest mean (mean) above 4 ,

Based on this analysis, it can be emphasized that one of the findings in this study is that job recruitment has a significant effect on the performance of the apparatus in the regional secretariat of Central Sulawesi province. These empirical findings are related to the effectiveness or influence of recruitment in general. Specifically, job recruitment is not surprising because theoretically, a leader with recruiting abilities who have competence in their field is an essential element in the recruitment process for state civil servants. (Lin \& Hsu, 2020).

Position Competence has a Partial (Positive) Effect on the Performance of State Apparatus in the Regional Secretariat of Central Sulawesi Province.

The second variable studied is the competence of the position. As evidenced in testing the hypothesis using frequency distribution analysis, the exogenous variable of job competence (X2) to the endogenous variable of the performance of the state civil apparatus (Y) turned out to have a significant contribution. Thus, this study objectively finds that job competence affects the performance of the state civil apparatus in the regional secretariat of the province of Central Sulawesi. In testing the hypothesis, it has been proven conclusively that the results of the analysis of the frequency distribution using SPSS obtained the highest average value (mean) of 4.34, which means that there is a significant effect of the variable of position competence (X2) on the performance variable of the state civil apparatus (Y), while the average value the smallest (mean) of 3 ,

Research has been carried out and proves that the performance of the state civil apparatus is significantly influenced by the competence of the position with an average value (mean) above 0.05 and is relevant to the findings. To provide a more comprehensive reinforcement while at the same time confirming field findings with a theoretical framework, several theoretical arguments are put forward which show that job competence affects the performance of the state civil apparatus.

Position Recruitment and Position Competence Together (Simultaneous) Have a Positive Effect on the Performance of State Civil Apparatus at the Regional Secretariat of Central Sulawesi Province

Based on the research findings, it is interesting to study further among the exogenous variables consisting of; job recruitment and job competence, which one has the most significant influence on the performance of the state civil apparatus in the regional secretariat of the province of Central Sulawesi. According to statistical methods, finding out the most significant influence between exogenous variables on endogenous variables is not too difficult; it is enough to look at the value of the results of the frequency distribution test. The average value (mean) in the most extensive frequency distribution is the variable that has the most influence on the performance of the state civil apparatus. It is clear that the frequency distribution for the job recruitment variable has the highest mean (mean) of 4.29; for the job competency variable, the highest mean (mean) is 4.49 .

Suppose we carefully understand the hypothesis testing that has been carried out and the partial discussion based on exogenous variables to endogenous variables, in general. In that case, it can be stated that job recruitment, job competence simultaneously have a significant effect on the performance of the state civil apparatus in the regional secretariat of Central Sulawesi province. However, to provide empirical evidence, it is ideal for showing the results of this research hypothesis testing.

Proportionately the magnitude of the direct effect of $\mathrm{X} 1$ on $\mathrm{Y}$ is $\mathrm{YX} 1 \times \mathrm{YX} 1$ or $0.678 \times 0.678=0.459$. The magnitude of the direct effect of $\mathrm{X} 2$ on $\mathrm{Y}$ is $\mathrm{YX} 2 \times \mathrm{YX} 2$ or $0.713 \times 0.713=$ 0.508 . Thus the magnitude of the effect of $\mathrm{X} 1$ on $\mathrm{Y}$ is $14.2 \%$, the total effect of $\mathrm{X} 2$ on $\mathrm{Y}$ is $34 \%$, in total the effect of $\mathrm{X} 1$ and $\mathrm{X} 2$ on $\mathrm{Y}$ is $10,459+0.508$ or $14.2 \%+34 \%=48.34 \%$. But this influence does not include influence through a correlative relationship but is still a direct influence. The hypothesis test above explains that partially (individually) all exogenous variables make a significant contribution to endogenous variables. Therefore, it can be seen simultaneously that the magnitude of the simultaneous effect is to achieve $48.34 \%$, the rest as residual variables but not studied in this study.

The finding that job recruitment has a significant effect on the performance of the state civil apparatus and position competence has a substantial impact on the performance of the state civil apparatus is not too surprising because apart from being relevant to previous research, each has a solid theoretical basis. However, when the most significant level of influence is found in the variable of job competence, then job recruitment becomes interesting to observe further because the theoretical assumptions built in this study do not seem to be 
different from the general conceptual understanding that job recruitment has more power to exert influence-greater impact on performance.

\section{Novelty Research/Novelty}

From several research journals that have been mentioned in the discussion related to the problem conditions in the background of this research, it can be seen that none discusses the effect of job recruitment on the performance of the state civil apparatus explicitly. Thus, it can be concluded that the research conducted is relatively new and has not been done by many previous researchers.

And this study provides evidence that the results of the analysis show objectively that job recruitment contributes significantly or has a significant effect on the performance of the state civil apparatus in the regional secretariat of Central Sulawesi province. In addition, from several indicators on the variable of job recruitment, it appears that the low percentage is an indicator of the recruitment method and the basis of recruitment so that it provides the assumption that recruitment problems that tend to be closed and do not use the merit system as a basis for an assessment result in the low professionalism of government officials in carrying out their duties. And its function.

\section{VI.CONCLUSION}

From the study results, it was found that job recruitment has a significant (positive) effect on the performance of the state civil apparatus in the regional secretariat of Central Sulawesi province by $14.2 \%$. Which means that the job recruitment process influences it. In the field of Position Competence, it has a significant (positive) effect on the performance of the state civil apparatus in the regional secretariat of Central Sulawesi province by $34 \%$. These results illustrate that civil servants have the ability and individual capacity to carry out various tasks in a job. Then the recruitment of Position and Position Competence simultaneously has a (positive) effect on the performance of the state civil apparatus in the regional secretariat of Central Sulawesi province by $48.34 \%$. In this case,

\section{REFERENCE}

[1] Adam, A. M. (2020). Sample Size Determination in Survey Research. Journal of Scientific Research and Reports, 90-97. https://doi.org/10.9734/jsrr/2020/v26i530263

[2] Ali, S. H., \& Sagsan, M. (2020). The Mediating role of Knowledge-Oriented Leadership Between Bureaucratic Culture and Knowledge Creation: The case of Public Universities in Northern Iraq. Proceedings of 21st European Conference on
Knowledge Management. 21st European Conference on Knowledge Management. https://doi.org/10.34190/EKM.20.066

[3] Alserhan, H. F., \& Shbail, M. O. A. (2020). The role of organizational commitment in the relationship between human resource management practices and competitive advantage in Jordanian private universities. Management Science Letters, 3757-3766. https://doi.org/10.5267/j.msl.2020.7.036

[4] As'ad, A., \& Kamidin, M. (2020). Pengaruh Kompetensi Dan Motivasi Terhadap Kinerja Pegawai Pada Balai Besar Industri Hasil Perkebunan Makassar. Celebes Equilibrum Journal, 1(2).

[5] Das, S. (2021). Extreme rainfall estimation at ungauged locations: Information that needs to be included in low-lying monsoon climate regions like Bangladesh. Journal of Hydrology, 601, 126616. https://doi.org/10.1016/j.jhydrol.2021.126616

[6] Delbari, S., Rajaipour, S., \& Abedini, Y. (2021). Investigating the relationship between career development and productivity with the mediating role of self-regulation among university staff. Journal of Applied Research in Higher Education, 13(3), 759781. https://doi.org/10.1108/JARHE-06-2019-0153

[7] Faiz, A., Astuti, R. S., \& Afrizal, T. (2020). Sistem Merit pada Sektor Pemerintahan: Proses Pengisian dan Penempatan Jabatan Pelaksana di Badan Kepegawaian Daerah Jawa Tengah. PERSPEKTIF, 9(2), 406-417. https://doi.org/10.31289/perspektif.v9i2.3878

[8] Hymel, G. (2002). The Qualitative Research Category and its Contextual/Interpretive-Oriented Research Strategy. In Research Methods for Massage and Holistic Therapies (pp. 145-171). Elsevier. https://doi.org/10.1016/B978-032303292-6.50018-3

[9] Lazarova, M., Dimitrova, M., Dickmann, M., Brewster, C., \& Cerdin, J.-L. (2021). Career satisfaction of expatriates in humanitarian inter-governmental organizations. Journal of World $\begin{array}{lll}\text { Business, } & 56(4), & 101205 .\end{array}$ https://doi.org/10.1016/j.jwb.2021.101205

[10] Lin, M.-H., \& Hsu, H.-C. (2020). Effects of a cultural competence education programme on clinical nurses: A randomised controlled trial. Nurse Education Today, 88, 104385. https://doi.org/10.1016/j.nedt.2020.104385

[11] Lohman, L. (2021). Evaluation of university teaching as sound performance appraisal. Studies in Educational Evaluation, 70, 101008. https://doi.org/10.1016/j.stueduc.2021.101008

[12] Mokodongan, D., Mantiri, M., \& Kumayas, N. (2019). Promosi Jabatan dalam Meningkatkan kinerja Aparatur Sipil Negara (ASN) Di Pemerintah Kota Kotamobagu. JURNAL EKSEKUTIF, 3(3).

[13] Mutiana, L., Diantimala, Y., \& Zuraida, Z. (2017). PENGARUH SISTEM PENGENDALIAN INTERN, TEKNOLOGI INFORMASI, KUALITAS SUMBER DAYA MANUSIA DAN KOMITMEN ORGANISASI TERHADAP KUALITAS LAPORAN KEUANGAN (STUDI PADA SATKER DI LINGKUNGAN KEMENTERIAN AGAMA KABUPATEN ACEH UTARA). JURNAL PERSPEKTIF EKONOMI DARUSSALAM, 3(2), 151-167. https://doi.org/10.24815/jped.v3i2.8228

[14] Rizun, N., Revina, A., \& Meister, V. G. (2021). Analyzing content of tasks in Business Process Management. Blending task execution and organization perspectives. Computers in Industry, 130, 103463. https://doi.org/10.1016/j.compind.2021.103463

[15] Setiawan, T. (2018). PEMBERDAYAAN SUMBER DAYA MANUSIA SEBAGAI INSTRUMEN PENINGKATAN KINERJA ORGANISASI. Media Mahardika, 16(3). 